This is a self-archived version of an original article. This version may differ from the original in pagination and typographic details.

Author(s): Lillie, Nathan; Berntsen, Lisa; Wagner, Ines; Danaj, Sonila

Title: A Comparative Analysis of Union Responses to Posted Work in Four European Countries

Year: 2020

Version: Accepted version (Final draft)

Copyright: @ Routledge, 2019

Rights: In Copyright

Rights url: http://rightsstatements.org/page/InC/1.0/?language=en

Please cite the original version:

Lillie, N., Berntsen, L., Wagner, I., \& Danaj, S. (2020). A Comparative Analysis of Union Responses to Posted Work in Four European Countries. In J. Arnholtz, \& N. Lillie (Eds.), Posted Work in the European Union: The Political Economy of Free Movement (pp. 89-108). Routledge. Routledge Research in Employment Relations, 46. https://doi.org/10.4324/9780429031021-5 


\section{Chapter 5 - A comparative analysis of union responses to posted work in four European countries}

Nathan Lillie, Lisa Berntsen, Ines Wagner, and Sonila Danaj

\subsection{Introduction}

Posted work poses a challenge to union labour market regulation. In the wake of the $2004 \mathrm{EU}$ enlargement, unions largely attempted to deal with posting by 'relocalising' labour relations by enforcing posted workers' rights under national collective bargaining agreements (CBAs), following a traditional union logic of solidarity and enlightened self-interest. In this chapter, we discuss how construction unions have experimented with new strategies for representing posted workers in Finland, the Netherlands, Germany, and the UK over the past decade. These efforts have resulted in the creative re-enactment of national institutions to regulate posted work more effectively. These union responses are taken from a familiar tool box of tactics applied to migrants generally but are extended and adapted to the needs of posted workers. In none of our cases, however, have unions found a sustainable way for posted workers to be union members. We argue that this problem is fundamental to the way posted work functions, and it presents a challenge to the labour market institutions of EU M ember States. Posted employment complicates union relations with workers, while legal barriers and employer evasiveness encouraged by the EU framework further inhibit unions from adequately enforcing workers' rights at the workplace level. In all our country cases, unions have committed significant resources to re-enact national labour market institutions to combat construction labour market dualisation and rule evasion by posting firms but with only limited success.

We look at the structure of wage regulation and its application to posted workers as well as union site-level representation in each of our country cases. Finland's system is the most effective at discouraging employers from rule evasion. This shifts employer interests away from deregulation in the direction of controlling transnational subcontractors on the site-level, although the system requires constant vigilance by unions. Dutch unions also have exploited their institutional position and legally extended CBAs to rein in abusive employer practices but are disadvantaged by a weaker site-level presence compared to the Finnish unions. In the UK, there is no legally extended industry agreement, so unions focus primarily on site-level agreements supported by strong shop floor organisations in engineering construction; in other construction subsectors, they have little influence. German unions have a sector minimum wage agreed via CBAs but lack site-level structures to enforce it. Although there are strong main contractor liability laws, they have difficulty encouraging posted workers to pursue cases. 


\subsection{How does posting affect union rights?}

Union rights are operationalised through national industrial relations (IR) systems. Each union movement is embedded within a nationally specific and bounded web of institutional relationships that together define worker rights and resolve the inevitable disputes around those rights (Zhang and Lillie, 2016; Lillie and Wagner, 2017). Posting, however, is institutionally set apart from national systems, demanding from unions strategic innovations to retain labour market control. Employers strategically evade posting rules in ways which increase management workplace control and worker discipline (Haakestad and Friberg, 2017) and reduce practical access to worker rights (Lillie 2016). The hyper mobile work-based nature of posting means that workers lack local attachments and do not join unions (Caro et al., 2015). It creates a 'mobility trap', undermining collective resistance because posted workers tend to regard moving laterally to other jobs as more real istic than demanding better treatment (Berntsen, 2016; M atryska, this volume). Their job contracts generally offer little in the way of enforceable employment protection, and recourse to labour courts is usually not practically available (Kall et al., 2018). Their employment is flexible, unpredictable, and timebounded.

\subsection{Union responses to posted work}

We characterise union strategies to regulate posted work as 5.3.1) migrant worker engagement, 5.3.2) political influence and regulatory enforcement, 5.3.3) collective agreement extension and enforcement, and 5.3.4) site-level structures.

\subsubsection{Migrant workerengagement}

The literature on migrant organising has detailed many successful cases of organising and mobilising precarious migrant workers (M ilkman, 2006; Berntsen, 2015; Connolly et al., 2017; Benvegnu et al., 2018). Posted workers, however, are more difficult to organise than other forms of precarious migrants. Recruitment efforts, although sometimes sophisticated and well-resourced, have not resulted in sustained posted worker membership or organisation (Lillie and Greer, 2007; Lillie and Sippola, 2011; Wagner and Lillie, 2014; Danaj and Sippola, 2015; Berntsen and Lillie, 2016). A documented exception to this is the union organising success at one Copenhagen metro construction project. Arnholtz and Refslund (2019) attribute this success to the extensive resources deployed, and the high-profile successes in recruiting the more skilled segments of the workforce.

Unions in our case countries have de-emphasised recruitment per se where posted workers are concerned, focusing more on 'engagement' than 'organising'. Recruitment and/or active mobilisation are not always necessary, from the perspective of enforcing the CBA. Less demanding, and, from the perspective of posted workers, less risky interactions such as providing information about wages and conditions, or anonymously giving their consent to and support for union activities, are also useful, and usually this is the level of engagement the unions seek (Berntsen and Lillie, 2016; Haidinger et al., 2018). 


\subsubsection{Politic al influence and regulatory enforcement}

The deregulation of the construction industry's labour market through free mobility occurs not as a removal of regulation, per se, but rather as an opening of ways to avoid regulation. Cheap labour suppliers in Western Europe seek not only to avoid CBAs but often also fail to fulfil bureaucratic requirements, safety rules, and labour laws (Cremers, this volume). In general, these things come as a package, presenting unions with an obvious ally in government agencies concerned with enforcing rules and collecting revenue. Politically strong unions, with institutionalised cooperation with government agencies, have better opportunities in this respect. This strategy involves pushing for tightening of the enforcement of national rules from all angles, on the assumption that while presenting no inconvenience for legitimate firms, it tends to drive rule-evaders out of the market.

\subsubsection{Collective agreement extension and enforcement}

Since, by definition, posted workers' employers are not based in the host country, they are also, by default, not signatories to host country CBAs. European Union jurisprudence essentially rules out strikes except to enforce existing extended CBAs, meaning that any wage regulation must be general and equally applied through legal mechanisms to organised and unorganised employers alike. Unions either need a universal wage standard to apply or some means to coerce the employer into negotiating. The 2018 revision of the PWD relaxes this requirement and also recognises unions' right to strike on behalf of posted workers. The effects of this change have yet to be tested in practice, but they have been characterised as making the rest of the EU M ember State frameworks more similar to the Finnish one (Interview at RL, 2019).

In all our cases, unions have searched for ways to bring more posted workers under the protection of CBAs to monitor the application of CBAs better and counter employer cheating. Various kinds of pressure are applied to main contractors, and unions have become more assertive about pursuing legal cases for wage recovery.

\subsubsection{Site-level structures}

Compliance by posted worker employers is rarely voluntary: It is either pro-active, anticipating enforcement, or reactive, reflecting enforcement that is occurring. Posted workers may or may not be aware of host country pay norms but rarely take action themselves to recover underpaid wages. Collective agreements require constant monitoring, which is most effectively accomplished by shop stewards. Additionally, main contractors sometimes monitor conditions in their contracting chain because of liability concerns, industrial disputes, or bad publicity.

In 'dual channel' systems, such as Germany and the Netherlands, unions have traditionally depended on legally independent works councils for access to workers. In single channels systems, such as the UK and Finland, representation occurs through shop stewards. While either system can be effective for industrial democracy (Turner, 1991), single-channel systems function better when confronted with transnational subcontracting and worker posting because of the firm-centric nature of works councils (Haidinger et al., 2018). In our cases, this is visible in the challenges faced by Dutch 
and especially German unions, who normally rely on works councils in establishing contact with the shop floor and conducting site-level monitoring.

\subsection{Finland}

A highly regulated labour market and strong national-level extended CBAs enforced through monitoring by trade union officials and shop stewards supplemented by government labour inspectors characterise Finland's posted work context. Union monitoring and pressure tactics, including secondary boycotts, combined with government policies to reduce the grey economy, have made it harder for transnational service providers to avoid regulations. Over time, the trend has been from regulation based primarily on union action to one based on state regulation, backstopped by union action. Finland's main construction union, Rakennusliitto (hereinafter RL), has over time become more sophisticated in its approach to migrant workers. Still, the complexity of contracting chains and the intransigence of many employers leave noncompliance with the Finnish CBAs a persistent problem.

The Finnish industrial relations system is based on sectoral CBAs and institutionalised tripartitism. The RL enjoys a membership density of between 70 and 80 per cent, bolstered by a modified Ghent-style social insurance system. The Industrial Union (TL) and the Electricians Union (SL) are also important in construction and have their own CBAs. Employers are represented by an industry association, Rakennusteollisuus, whose members include almost all large construction employers in Finland, and an association for small employers, Suomen Yrittäjät. Members and nonmembers alike are bound by legally extended CBAs.

Since 2004, EU free movement has increased the number of workers coming from Eastern Europe and the Baltic States. In the period following the 2004 accessions, revelations of poor labour practices among foreign-based subcontractors emerged regularly in the Finnish media. Typically, these involved very low pay, poor living conditions, extensive (unpaid) overtime hours, misclassification of workers into lower pay grades, and unpaid social benefits. Finland imposed a transition period on the free movement of workers from new CEE M ember States in 2004, but this ended in 2006 because the unions concluded that migrants were being channelled into posting instead of moving as individuals. Still, the transition period had a lasting impact because Estonian firms using posted labour had become ensconced in the Finnish construction market.

The situation improved as better union strategies, including close monitoring and pressure tactics such as secondary boycotts, and government policies to reduce the grey economy made it harder for transnational services providers to avoid regulations. Estonian workers have become less precarious in the Finnish job market (Sippola and Kall, 2016). Nonetheless, there is still an impression among unionists that many employers do not comply with the CBA (Interview at RL, 2018).

Posting employers are legally required to comply with industry collective agreements for those aspects of remuneration enumerated in the PWD. Finnish unions frame the posting problem in terms of protecting CBA conditions and assisting mistreated posted workers. Usually, the second objective is achieved through the first because all posted workers in construction are legally entitled 
to receive wages corresponding to the skill level of their job category, per diems, travel reimbursements, and various other supplements.

In the period immediately after eastern accession, the RL developed a blacklisting strategy for contractors in serious violation of the CBA. Contractors working with blacklisted firms may be subject to site-level secondary industrial action or 'blockades'. The system is a deterrent and remedy of last resort - subcontractor firms avoid blacklisting, and main contractors avoid associating with those on the blacklist. Usually, it is sufficient to inform the main contractor of a problem or that a blacklisted subcontractor is on site: The main contractor will generally fix the problem and/or end the relationship before a blockade becomes necessary. The extended CBA provides Finnish unions with legal grounds for using industrial action if contractors, including foreign subcontractors, violate it. Blockades are rarely needed since blacklisting mostly works on the reputational concerns of the main contractors. The RL has good connections with the press ensuring that cases that are not resolved promptly are well covered in the press. Tightening enforcement of government regulations means that the RL sees itself as less reliant on blockades and media coverage than in the past, but the strategy is still used.

As part of a general campaign to combat 'grey' work in the post-EU accession period, Finnish unions developed close cooperation with authorities such as the Finnish labour inspection. The RL lobbied for and received stronger regulatory enforcement specifically designed to monitor foreign firms as well as domestic ones. These measures involve worksite access controls, such as increased ID card requirements for access to construction sites, tighter foreign-service provider registration requirements, and better monitoring by tax authorities. According to $\mathrm{RL}$, these measures have helped to reduce fraud and non-compliance with the CBA on large sites, although for small sites there is still often no monitoring at all.

Finnish construction unions have strong shop floor structures, and on multi-union sites, the Industry Union and the Electricians' Union, for example, participate cooperatively in site-level governance. RL's policy of informing and recruiting workers, as well as checking for violations of the CBA, works both through these inter-firm site-level shop steward networks, and through site visits by RL officials.

A major change that occurred over the last decade or so is the increased understanding of how to recruit migrant workers as members, reflected in the growing number of migrant workers who are members. RL has created a special 'migrant' department to encourage participation by migrant members (Alho, 2013). RL representatives make a point of helping migrant workers with everyday things (such as taxes and housing), in order to project a positive image. Communication is often problematic, but among the largest group - Estonians - there are often Finnish speaking workers (M anninen interview, 2014). Still, posted workers remain, by and large, unorganised. With them, the main objective has been to get the necessary information to combat underpayment, by pressuring the employer via the main contractor, taking the matter to court, or organising a site blockade. It is clear, from interviews with Estonian construction workers (members and nonmembers, posted and not) that the profile and reputation of RL have increased among Estonian construction workers during the past decade or so (Sippola and Kall, 2016).

The Olkiluoto 3 nuclear power plant construction case is an example where extensive posting was used. The main contractors successfully sought to establish the site as an exceptional zone, 
largely free of union influence. Wage and social security violations were common and frequently in the news. At the outset of construction in 2005 , site management signalled its intentions to the unions by trying to deny access to union representatives. This precipitated a union blockade, but the number of union members on the site was insufficient to give the RL leverage. Access was granted, but on unfavourable terms which made it difficult to monitor the site. Union efforts continued, including the appointment of a safety committee of shop stewards, but the unions were unable to prevent frequent and severe CBA violations (Lillie and Sippola, 2011). Beginning in 2011, however, the electricians' union made headway in organising posted Polish electricians; these workers had been underpaid according to the extended CBA, so the union took the case to the labour tribunal. The tribunal referred key questions of European law to the CJEU, resulting in the so-called sähköalojen ammattiliitto decision, which confirmed the union's claims of underpayment, as well as the enforceability of the CBA's most important provisions on posted workers. The case demonstrates that while the blockade tactic may be effective with Finland-based main contractors, only with the development of a more varied toolkit including worker engagement strategies could they extend their influence on recalcitrant foreign main contractors.

\subsection{The Netherlands}

The Dutch regulatory system for posted work relies on extended sectoral CBAs monitored by the social partners. CBA coverage is comprehensive, and unions have committed extensive resources and applied innovative techniques for representing and engaging with posted workers. Public authorities have also been cooperative and, since 2015, instated chain liability. There is, however, a tendency by firms to evade tightening enforcement through labelling posted workers as selfemployed. Unions have used media pressure, protests, pickets, and posted worker engagement at various occasions to bring leverage against recalcitrant employers. Over the long term, the trend has been towards a comprehensive approach of tightening regulation involving increased labour inspection and cooperation with employers. Despite this, enforcement remains a challenge.

The Dutch system of industrial relations is based on an institutionalised tripartite social partnership, magnifying the Dutch unions' influence in national labour policy. There are two major unions in construction, divided on ideological lines with the sectoral union of the social-democratic FNV representing three-fourths of the industry, while the (smaller) Christian democratic CNV covers about one-fourth of the workers (Eurofound, 2015, 21). The average union density in the Netherlands is around 17 per cent, but in construction, it is higher (30 per cent in 2011). Posted workers rarely become union members and, if they do, only for limited periods.

Though the Netherlands imposed transitional measures after the 2004 enlargements, Dutch unions were divided on this. The FNV opposed restrictions as it might encourage undeclared labour, while CNV supported restrictions to cushion migrant labour inflows. Compared to Germany, the Dutch construction labour market is less affected by posted work, except on large construction sites (SER, 2014, 173). A major issue has been a spectacular rise in self-employment: from one in eight in 1990 (SER, 2014, 169) and one in five in 2000 (EIB, 2017, 59) to almost half in 2018. Of the 7,000 Polish migrants working in Dutch construction in 2015, 65 per cent were registered as self- 
employed; as were 90 per cent of the 2,200 Bulgarian construction workers (CBS, 2017). The extent to which self-employed construction workers are mislabelled is, however, contested, with estimates ranging from 5 to 70 per cent (SER, 2014, 171).

Similar to Finland, Dutch CBAs are legally extended over whole sectors by government decree, so that coverage is substantially higher than union density (around 80 per cent). The legally extended CBAs do not apply to self-employed workers. Dependent posted workers, however, are automatically covered for those aspects specified in the PWD. While there is a high level of cooperation between the labour inspectorate and unions, labour inspectors do not enforce the CBA. The inspectorate enforces the labour laws related to the statutory minimum wage, holiday allowance, and working times. Enforcement of the higher hourly CBA wage is in the hands of the unions. Whereas the labour inspectorate has access to workplaces, Dutch union officials do not, except when granted by site management. Dutch unions also cannot force companies to open their books to monitor compliance with CBAs (only the labour inspectorate has this authority).

Posting is addressed by Dutch unions as part of a larger fight against 'bogus employment constructions', which include other types of dubious employment arrangements and abuses of precarious workers. While efforts are made to recruit migrant workers, the main approach is to strengthen CBA enforcement. In light of the increased non-compliance, the FNV established in 2014 a compliance and enforcement department (Team Handhaving and Naleving) focusing on sectors that are more liable to non-compliance, such as construction (FNV, 2013). This department fights rights violations and bogus employment constructions targeting mainly larger projects.

Unions signed a social pact with the Dutch government in 2013 (Sociaal Akkoord). Included in this agreement was the expansion of the labour inspectorate's resources to fight bogus employment constructions. Since 2016, the labour inspectorate prioritised compliance monitoring of wage payments and working hours, increasing the enforcement percentage in the construction sector from 19 per cent in 2015 to 37 per cent in 2016 (Inspectie SZW, 2017).

Union lobbying efforts for stricter industry regulations resulted in the July 2015 Law against Bogus Constructions (Wet Aanpak Schijnconstructies (WAS)). The WAS instituted chain liability in contracting, increasing unions' leverage to pursue wage claims and pressure contractors into CBA compliance. The law improved migrants' access to courts for wage claims and sought to encourage main contractors, especially in construction and metalworking, to take a proactive stance towards preventing underpayment by their subcontractors. (Van Drongelen and De Kort, 2016). However, wage recovery for migrants remains problematic (M inisterie SZW, 2017, 4). Since the WAS, information-sharing and collaboration between the labour inspectorate and unions intensified and improved (Cremers, this volume).

Dutch unions have made notable advances in organising migrant workers. They have had successful strikes involving migrant workers (see Connolly et al., 2017; Berntsen, 2015). On occasion, they have sought to mobilise posted workers but with only limited success. M otivating posted workers to interact with the union has been challenging, as most prefer to remain anonymous out of fear of dismissal. Similar to the Finnish unions, but in contrast to the situation in Germany or the UK, Dutch unions have the standing to instate legal proceedings to enforce the CBA, even if the workers in question decline to pursue the case. They do, however, often need information from the workers to prove their legal case. 
In contrast to Finland, site-level representation is weak. Even on large sites, Dutch unions have few options to monitor the working conditions of posted workers. Sometimes, the unions establish union offices on sites, but this is contingent on successful local negotiations. The FNV union approach towards the construction sites in the Eemshaven is exemplary of the difficulties Dutch unions face in representing and protecting posted workers.

At the Eemshaven construction sites, around two-thirds of the 3-4,000 workers came from abroad, mostly from EU M ember States. The construction process was characterised by long contracting chains, consisting of Dutch and foreign subcontractors as well as temporary agency firms. The FNV found numerous violations of the Dutch CBA conditions among foreign workers, especially those employed in the lower echelons of the contracting chain. While the union informed migrant workers of their rights by leafleting at the construction site entrance and hosting regular union office/information hours on the worksite and at the accommodations and tried to persuade larger groups of workers to come forward with rights claims, the main progress to improve working conditions was made through union-management negotiations and judicial proceedings (Berntsen and Lillie, 2016). Out of fear of employer retaliation, most migrants refused to support the union's claims or supported them only anonymously (ibid.). The smaller the firm that employed the migrants, the more difficult it was to protect the workers once negotiations, pressure tactics, and litigation proceedings were instated.

Distribution of information to migrant workers about Dutch CBAs and labour law receives limited attention in the Netherlands compared to other EU M ember States. There is, for instance, no Dutch equivalent of the German Fair M obility information centres. A sector-overarching project which serviced, informed, and mobilised Polish migrant workers took place from 2013-2015 but was not continued (Roosblad and Berntsen, 2017). Dutch unions work closely in particular cases with the government-funded NGO FairWork, located in Amsterdam, that fights against modern slavery in the Netherlands and assists migrants (including undocumented and EU migrants) in wage claims.

\subsection{Gemany}

The German industrial relations system is a dual system in which unions and employers conduct collective bargaining while works councils represent workers in the workplace. IG BAU represents building sector workers. There are two national-level bargaining partners on the employer side whose members are legally bound to follow collective agreements and account for a substantial portion of the legal domestic construction industry. The German system of worker representation has often been characterised as prone to labour market dualisation because of the firm-centric works councils. Insofar as the regulation of posted work at the workplace level is concerned, the dual system places unions at a structural disadvantage because their channel of access - works councils - is fragmented by the firm. Works councils in main contractor firms have almost no rights to represent subcontract workers (Däubler, 2011, 6). M oreover, German co-determination legislation does not apply to subcontractors based outside Germany (Wagner and Lillie, 2014). As a result, migrant workers who are employed via subcontractors have no right to representation by the works council of the client firm. 
The regulatory environment was largely affected by the free movement transition period for 2004 and 2007 for accession countries. In contrast to Finland and the Netherlands, Germany also enacted restrictions for a transitional period on the cross-border provision of services, so posted work was also affected (Donders and Sengers, 2009, 56). Unions argue the transition periods gave them time to revise the collective bargaining framework and strengthen the regulatory framework (DGB, 2006, 17). However, some authors argued that it was precisely these transition periods that caused migrant workers to move into undocumented and exploitative work (Cyrus, 2006).

German CBAs cover only member organisations, so in the absence of statutory minimum wages (until 2014), wages at foreign service providers were unregulated. To address this gap, a group of trade unions and employers' organisations jointly requested the Federal M inistry of Labour to declare the lowest pay grade in their sectoral CBA generally binding for their industrial sectors. These 'industry-specific minimum wages' subsequently became reference points for new public procurement laws that Länder began passing already in the 1990s, thereby giving the commissioning authorities an additional lever to enforce these minimum wages.

Collective agreements in construction set out minimum wage levels; posted workers tend to be placed in the minimum category. However, the CBA also specifies that employers must pay per diem, travel reimbursements, and housing to posted workers. In principle, all posted construction workers should be covered by the industry minimum wage and wage supplements. The problem, as with the Dutch and Finnish cases, is ensuring compliance. Compared to Finland, IG Bau faces difficulties because of its weaker connection to the shop floor. Trade unions have the right to access work sites if they have a member working there. They do not perform official site checks, but talk to employees informally, to establish rapport and exchange information. However, posted workers are not normally members, and site representation, such as processing of grievances, occurs through works councillors, who are confined to their firm. To access posted workers, German unions have had to be innovative (see, for example, the European Migrant Workers Union, Greer et al., 2013). Most obviously, IG Bau represents individuals or groups of migrant workers who come to it with complaints. However, this has not proven sufficient, and other outreach methods have been attempted.

The main strategy to inform, assist, and possibly organise temporary cross-border EU migrant workers is through so-called 'Fair M obility' service centres established across Germany. These are funded 80 per cent by the Ministry of Labour and 20 per cent by the German Federation of Trade Unions. In these service centres, project workers with relevant language skills inform migrants about labour law and social legislation in their native languages (Wagner, 2015). They also collaborate with other civil society organisations to help workers with employment and social issues. There are currently 10 service centres across Germany; they are open to all migrant workers but have a focus on intra-EU migration.

The staff at the Fair M obility centres engage in active organising, visiting locations where migrant workers can be found, and also organise events. Although Fair M obility staff do not directly recruit workers into union membership, they make it clear in their materials and conversations that workers can join the relevant union for their sector.

IG Bau does not have a tradition of conducting industrial action outside of collective bargaining nor the site-level structures which would enable solidarity strikes on behalf of posted 
workers. Instead, they rely on protests and legal cases, which because of Germany's strong main contractor liability laws, have a chance to succeed in recovering back pay; these, however, require the workers to take up the case, as well as resources to follow through.

One strategy that can be identified is that legal cases and protests are often combined strategically. In such cases, posted workers and IG Bau representatives picket the construction sites where the abuses occur. IG Bau seeks to draw media attention to the case. The idea is to motivate the main contractor to pay the workers, or to pressure the subcontractor to do so, and avoid lengthy court proceedings for wage recovery, where the main contractor has powerful financial resources to fight the case. Such actions usually only take place when posted workers are truly desperate, having found themselves without pay for an extended period. An example of how the posted worker representation system works is a joint action between IG Bau, a Fair M obility centre, the EM WU, and posted workers from Romania. In 2014, a group of 50 Romanian construction workers contacted the Fair M obility centre in Frankfurt am M ain. The men had done carpentry work since November 2013 on a hotel construction site but had received little pay for several weeks. The Fair M obility centre raised donations to provide the workers with necessities. The subcontractor had promised the construction workers a net wage of 1200 euros. In February, the posted workers downed tools and picketed the construction site, demanding their wages. The main contractor offered each worker 100 euros and a ticket back to Romania. The posted workers collectively rejected the offer, claiming they were due over 100,000 euros in back pay. With union support, the workers continued their pickets, which receive coverage in the regional media. After months of protest and negotiations, the main contractor agreed to pay out 100,000 euros to the 50 workers (DGB, 2015). Cohesion among the workers was key to success in this case, but so also was the threat of main contractor liability, which could have forced management to make the same payment after costly court proceedings.

Germany has long had a comprehensive chain liability system, allowing subcontractor workers to pursue claims of unpaid wages. The rules on liability in a subcontracting chain cover the employers' obligations to withhold tax on remuneration for building services, pay social security contributions, and pay wages, including holiday payments. Rates of enforcement on behalf of posted workers are still low, however. Nonetheless, trade unions praise the instrument as a useful threat, but one which needs further development (Bogoeski, 2017). The difficulty is that violations must be proven and workers persuaded to take up cases. Here, the German unions' lack of presence on job sites and the difficulty of persuading posted workers to become active mean they cannot take full advantage of the potential of chain liability.

\subsection{The United Kingdom}

In the UK, the monitoring of posted work is fairly strict in industrial construction, and very weak elsewhere. British unions did not contest free mobility following the 2004 enlargement, but also did not protest the restrictions imposed on Bulgarian and Romanian workers in 2007. They have been critical of posting, which they consider a threat to local jobs and collective agreements. After several wildcat strikes in 2008-2009, GM B and Unite the Union, the two main construction unions in the country, managed to include terms and conditions of hiring posted workers in the CBA of the 
engineering construction industry, while continuing to lobby for the application of the agreement to as many workplaces as possible and to monitor large sites via workplace representatives. They have been inclusive of posted workers on the shop floor and have also supported individual posted workers' claims (Fitzgerald, 2010; M eardi et al., 2012). Main contractors on large projects have generally agreed to monitor standards in their supply chains to avoid unofficial eruptions of industrial unrest, which even on a small scale can be very disruptive.

The British industrial relations system is highly decentralised, and there is little coordination in collective bargaining. Trade unions and employers enter voluntary relations, meaning CBAs do not have legal force and are signed predominantly at the workplace or establishment level. British construction workers are members of either GM B or Unite the Union. Union density in UK construction was 12 per cent in 2016 (Arnholtz et al., 2018), but engineering construction has a long tradition of militancy (Korczynski, 1997), and union density there is reportedly 70 per cent (Gall, 2012, 413). The construction sector is regulated by the Construction Industry J oint Council: the Working Rule Agreement used in civil engineering and commercial building construction, and the National Agreement for Engineering Construction Industry (NAECI) is applicable in engineering construction.

Under the constraints of limitations on industrial action and the voluntary nature of the CBAs, British unions have tried to address posted work in various ways. They have leveraged contractors of major public works through their clients, which has been successful in power station construction. They have also bargained to make agreements signed by the main contractor binding along the subcontracting chain, ensuring that posted workers in engineering construction are paid the same as locally hired workers. In this way, chain liability was enforced in several sites such as Carrington CCGT (combined cycle gas turbine) Power Station and Ferrybridge (coal-fired) Power Station (Danaj and Sippola, 2015). In Carrington and Ferrybridge, the unions tried to restrict the number of posted workers on NAECI sites to 20 per cent. Despite these successes, the voluntary nature of CBAs ensures that while the British system functions well on large sites with site-level agreements, it functions badly everywhere else.

Legal restrictions make strike action difficult (Bogg, 2016). There is, nonetheless, a tradition of industrial action, and on large construction sites, there are strong shop floor union structures. So, while official strike action over posted work is completely absent, there have been notable wildcat strikes such as the Staythorpe and Grain disputes of 2008 and the Lindsay Oil Refinery dispute of 2009. Under the slogan 'British jobs for British workers', strikers argued British workers were excluded from working on engineering construction sites, and posting was used by employers to undermine the CBA (Barnard, 2009; M eardi, 2012). As a result, equal pay for posted workers was included in subsequent NAECl agreements (See Appendix G of NAECI 2013-2015 and 2016-2018). Unions have not been as successful in having employers abide by the CBA at smaller projects.

To enforce the agreement along the subcontracting chain, unions on large sites appoint two senior shop steward officials, one from UNITE and one from GMB, who are employed by the main contractor and who overview the implementation of the CBA across subcontractor lines. Also, elected shop stewards operate at each contractor. In the UK, as elsewhere, very few posted workers join the unions. In both Ferrybridge and Carrington, around 20 per cent of posted workers became members. Recruitment strategies in the workplace included the dissemination of information on the 
CBA and union services through oral presentations, leaflets, or posters, and the organisation of sitelevel union meetings. Despite these efforts, posted workers usually join when they have not been paid and because union representation is conditional on membership. This was the case in Ferrybridge, where unions pursued several posted worker grievances against various subcontractors. Despite the low numbers of unionised posted workers at both sites, the enforcement of the CBA through the senior shop stewards proved an effective mechanism of protection for posted workers. Unions have successfully pursued posted worker pay claims. Some claims have been resolved the workplace level, while others were sustained by the National J oint Council, which is the highest joint employer-union body monitoring the CBA. They have, however, had difficulties in making some nonUK companies comply with rulings if the foreign contractor leaves the country, ceases to exist, or rebrands (Danaj, manuscript).

Unlike in the other cases, there has not been detailed union-backed legislation to plug the loopholes created by the growth of posted work in national collective bargaining. Faced with their moderately strong organisational power and problems stemming from structural weaknesses and low institutional power, British unions' political action in recent years has relied on discursive power (Coderre-LaPalme and Greer, 2017); this, however, has not been conducive to the kind of problemsolving policy cooperation seen in Finland and the Netherlands, or even Germany. British unions campaigned against the new anti-union act of 2016, which further limited their scope of action. Before the Brexit referendum, unions suspected the government wastrying to obstruct EU legislation to improve workers' terms and conditions. Unite even threatened to support Brexit if government proposals during the negotiations on the changes to the relationship with the EU included undercutting workers' rights (Jensen and Snaith, 2016).

\subsection{Analysis}

Worker posting in the construction industry introduces the possibility for creative evasion tactics from lower-wage contractors that avoid local collective agreements, minimum wages, and labour laws. Unions vary significantly, however, in how they deal with this. Given the dynamic nature of the problem, unions' tactical innovation and worker mobilisation potential are crucial to re-establishing labour market regulation. In 2007, Lillie and Greer argued that the mobilisation capacity of the unions was key to establishing effective regulation of posted work. Our cases suggest that while this is still important, there are now some institutional developments which regularise the regulation of posted work so that successful representation does not always need to involve successful posted worker mobilisation. Under pressure from institutional conversion, unions have responded with partially successful strategies of national institutional re-enactment.

This is evident in all our four country cases, although each case is uniquely shaped by its national institutional environment and the nature of union power resources. In some respects, the paths followed by unions keep to traditional national archetypes, but they also sometimes reflect experimentation with new strategies such as organising, which has not been used successfully on posted workers but has, nonetheless, influenced union discourses and forms of worker engagement. 
[INSERT FIG 5.1 HERE]

In all our cases, despite posted workers rarely joining unions, unions have represented them by extending their CBA coverage. This suggests, as per Doellgast et al. (2018), that the logic of union action in the face of increasing numbers of precarious workers is not towards dualisation but instead towards inclusive enforcement of collective agreements, even at a financial cost to the unions. Unions see equal pay as a way to ensure posted workers are treated fairly, but also as a way to stabilise the labour market.

Transnational service providers are often strategically evasive using their lack of established presence to escape union demands. In situations where employers can dismiss their workers and leave the country, comprehensive site-level monitoring and enforcement, combined with the ability to pressure main contractors, quickly and flexibly determine how well unions can respond to abuses. Finnish unions have the most developed and systematic approach. Dutch unions have developed sophisticated tactics to fight bogus employment constructions and have built relations with site management and labour inspectors. Chain liability since 2015 has strengthened union enforcement and negotiation leverage, but unions remain handicapped by weak shop-floor structures. German unions have little site-level presence and cannot rely on works councillors for posted worker complaints, leaving them reliant on protests and individual court cases, through the chain liability mechanism and media attention. In this, they are aided by the Fair M obility centres, which help locate and communicate with workers.

In the UK, large sites in engineering construction often have effective site-level agreements, giving unions some influence over conditions at transnational subcontractors. These reflect a postLindsey settlement and the possibility of unofficial industrial action. Unlike in Finland, this industrial action cannot be built into a formal system, which would allow the settlement to be generalised, because of legal restrictions on strikes. The result is segmentation between well-regulated large engineering projects and poorly regulated smaller sites. A certain amount of segmentation is seen in other cases as well; even in Finland, bigger sites are better regulated. In Germany, this difference is not so clear since the large sites are also poorly regulated.

Past European legislation and jurisprudence favour the legal extension of collective agreements or minimum wages; the revised Posted Workers Directive is more permissive regarding collective agreement application, so this may change as the directive is implemented. In Finland and the Netherlands, the legal extension of collective agreements is a long-standing practice, which is well suited to the post-Laval legal environment. In Germany, it is more recent and embeds inequality because the posted worker wage is lower than the normal CBA wage - and also not very well enforced. The UK practice of gaining subcontractor compliance through relations with the main contractor - concerned about possible disruptions from informal industrial action - gives the unions practical options for regulating posted work and handling posted worker grievances. 


\section{References}

Alho R. (2013) Trade union responses to transnational labour mobility in the Finnish-Estonian context. Nordic journal of working life studies 3 (3): 133-153.

ArnholtzJ. and Refslund B. (2019) Active Enactment and Virtuous Circles of Employment Relations: How Danish Unions Organised the Transnationalised Copenhagen Metro Construction Project. W ork, Employment and Society https://journals. sagepub.com/doi/pdf/10.1177/0950017019832514

Arnholtz J., M eardi G. and Oldervoll J. (2018) Collective wage bargaining under strain in northern European construction: Resisting institutional drift? European Journal of Industrial Relations 24 (4): 341- 356

Barnard C. (2009) The UK and posted workers: the effect of Commission v Luxembourg on the territorial application of British labour law: case c-319/06 Commission v Luxembourg, judgment 19 June 2008. Industrial Law Journal 38 (1): 122-132.

Benvegnú C., Haidinger B. and Sacchetto D. (2018) Restructuring Labour Relations and Employment in the European Logistics Sector. In Doellgast V, Lillie N, and Pulignano V. (Eds.) Reconstructing solidarity: Labour unions, precarious work, and the politics of institutional change in Europe. Oxford: Oxford University Press.

Berntsen L. (2015) Stepping up to strike: a union mobilization case study of Polish migrant workers in the Netherlands. Transfer: European Review of Labour and Research 21 (4): 399-412.

Berntsen L. (2016) Reworking labour practices: on the agency of unorganized mobile migrant construction workers. Work, employment and society, 30 (3): 472-488.

Berntsen L. and Lillie N. (2016) Hyper-mobile migrant workers and Dutch trade union representation strategies at the Eemshaven construction sites. Economic and Industrial Democracy, 37 (1): 171-187.

Bogoeski, V. (2017) Chain liability as a mechanism for strengthening the rights of posted workers: The German chain liability model, PROMO research report, http://www.solidar.org/system/downloads/attachments/000/000/839/original/Chain_Liability_as_a _mechanism_for_strenghtening_the_rights_of_posted_workers.pdf?1541517941

Bogg A. (2016) Beyond Neo-Liberalism: The Trade Union Act 2016 and the Authoritarian State. Industrial Law Journal 45 (3): 299-336.

Caro E., Berntsen L., Lillie N. and Wagner I. (2015) Posted migration and segregation in the European construction sector. Journal of Ethnic and M igration Studies 41 (10): 1600-1620.

CBS (Dutch Statistics) (2017) M igranten werkzaam in de bouw. Den Haag: CBS.

Coderre-LaPalme G. and Greer I. (2017) Dependence on a hostile state: UK trade unions before and after Brexit. In Lehndorff S, Dribbusch $\mathrm{H}$ and Schulten T. (Eds.) Rough Waters. European Trade Unions in A Time of Crises, Brussels: ETUI, 245-270. 
Connolly H., M arino S. and M artinez L. M. (2017) 'Justice for Janitors' goes Dutch: the limits and possibilities of unions' adoption of organizing in a context of regulated social partnership. Work, employment and society 31 (2): 319-335.

Cremers J. (2017) Drie jaar ervaring met intensievere cao-naleving: Een analyse van de nalevingsdossiers n.a.v. het Sociaal Akkoord 2013. Tilburg: Tilburg Law School.

Cyrus N. (2006) Die Übergangsregeln zur Einschränkung der individuellen Arbeitnehmerfreizügigkeit. Eine kurzsichtige Maßnahme ohne erhoffte Wirkung. In: Flore M.; Herletżus, A.; Schlatermund, H. (ed) Arbeit und Wohlstand im erweiterten Europa - AUSTER. Beiträge einer Kontroverse über Konsequenzen und Gestaltungsmodelle der europäischen Erweiterung. Osnabrück 2006: Arbeit und Leben, 90-110.

Danaj S. (manuscript) Defending Workers' Rights in Multi-Employer Workplaces: The Example of British Unions in the Engineering Construction Industry.

Danaj S. and Sippola M. (2015) Organizing posted workers in the construction sector. In Drahokoupil J. (Ed.) The outsourcing challenge: organizing workers across fragmented production networks. Brussels: ETUI.

Däubler W. (2011) Regulierungsmöglichkeiten im Zusammenhang mit Werkverträgen. Eine Expertise von Prof. Dr. Wolfgang Däubler im Zusammenhang mit Werkverträgen im Auftrag der Bundestagsfraktion DIE LINKE. Berlin.

Muotoiltu: hollanti (Alankomaat)

DGB - Deutscher Gewerkschaftsbund (2006) "EU-Osterweiterung: Übergangsregelungen beibehalten." Beschluss des Bundesvorstandes des Deutschen Gewerkschaftsbundes vom 04.04.2006. Retrieved 03/03/2019, http://www.de.migrationonline.de/data/beschldgbbv040406 bergangsregelungen 2 1.pdf?pid=426

DGB - Deutscher Gewerkschaftsbund (2015) Erfold für Rumänische Baurbeiter. Elnblick: Gewerkschaftlicher Info-Service 5.

Doellgast V., Lillie N., and Pulignano V. (ed.) (2018) Reconstructing solidarity: Labour unions, precarious work, and the politics of institutional change in Europe. Oxford: Oxford University Press.

Donders P. and Sengers K. (2009) Research on implementation of Posting Directive 96/71/EC. In Cremers J. and Donders P. (Eds) The Free M ovement of Workers in the European Union. Brussels: European Institute for Construction Labour Research, 15-56.

EIB (2017) Trends op de bouwarbeidsmarkt 2017-2022. Amsterdam: Stichting Economisch Instituut voor de bouw.

Eurofound (2015) Representativeness of the European social partner organisations: Construction sector. Dublin: Eurofound.

Fitzgerald I. (2010) Improving best practices on the working and living conditions of posted workers. Country Report UK. 
FNV (2013) FNV start 'cao-politie'. Webpost on 26 November 2013, Available at: «ttps://www.fnvbondgenoten.nl/nieuws/nieuwsarchief/2013/november/664891FNV_start_bureau_naleving/ > [Accessed 7 November 2014]

Gall G. (2012) The engineering construction strikes in Britain, 2009. Capital and Class, 36 (3): 411 431.

Greer I., Ciupijus Z. and Lillie N. (2013) The European M igrant Workers Union and the barriers to transnational industrial citizenship. European Journal of Industrial Relations 19 (1): 5-20.

Haakestad H. and Friburg J. H. (2018) Deskilling revisited: Labour migration, neo-Taylorism and the degradation of craft work in the Norwegian construction industry. Economic and Industrial Democracy DOI: 10.1177/0143831X17735671

Haidinger B., lannuzzi F., Sacchetto D., Lillie N. and Kall K. (2018). Enhancing Economic Democracy for Posted Workers. PROM O report. Available at

http://www.solidar.org/system/downloads/attachments/000/000/823/original/Enchancing_Econom ic_Democracy_for_Posted_Workers_-_PROM O_report.pdf? 1541517126 [Accessed 6 January 2019]

IG BAU / ZDB (2013) Kaum Nachwuchs, hohe Schäden, schlechter Ruf - Bilanz zu 10 Jahren fehlender M eisterpflicht im Fliesenlegerhandwerk: Ohne Korrektur stirbt der Berufszweig. Joint press release from 1 November 2013.

Inspectie SZW (2017) Jaarstukken Inspectie SZW : Jaarverslag 2016. Den Haag: SZW.

Jensen M. D. and Snaith H. (2016) When politics prevails: the political economy of a Brexit. Journal of European Public Policy 23 (9): 1302-1310.

Lillie N. and Greer I. (2007) Industrial relations, migration, and neoliberal politics: the case of the European construction sector. Politics \& Society 35 (4): 551-581.

Lillie N. and Sippola M . (2011) National unions and transnational workers: the case of Olkiluoto 3, Finland. Work, employment and society 25 (2): 292-308.

Lillie N. and Wagner I. (2017) Practicing European Industrial Citizenship. In Wiesner C., BjörkA., Kivistö H. M. and Mäkinen K. (Eds) Shaping Citizenship: A Political Concept in Theory, Debate and Practice. London: Routledge.

Lillie N. (2012) Subcontracting, posted migrants and labour market segmentation in Finland. British Journal of Industrial Relations 50 (1): 148-167.

Lillie N. (2016) The right not to have rights: posted worker acquiescence and the European Union labor rights framework. Theoretical Inquiries in Law 17 (1): 39-62.

Meardi G. (2012) Union immobility? Trade unions and the freedoms of movement in the enlarged EU. British Journal of Industrial Relations 50 (1): 99-120.

M eardi G., Martin A. and Riera M . L. (2012) Constructing uncertainty: Unions and migrant labour in construction in Spain and the UK. Journal of Industrial Relations, 54 (1): 5-21. 
Milkman R. (2006) LA story: Immigrant workers and the future of the US labor movement. Russell Sage Foundation.

M inisterie SZW (2017) Tweede monitor Wet aanpak schijnconstructies, M inisterie SZW: The Hague.

Roosblad J. and Berntsen L. (2017) The Netherlands: Finding common ground in an increasingly fragmented workforce. In Marino S., Penninx R. and Roosblad J. (eds) Trade Unions and M igrant Workers. Edward Elgar Publishing.

SER (2014) Arbeidsmigratie. Advies nr. 9 aan de Minister van Sociale Zaken en Werkgelegenheid. December. Den Haag: SER.

Sippola M. and Kall K. (2016) Locked in inferiority? The positions of Estonian construction workers in the Finnish migrant labour regime. Comparative Social Research, Labour M obility in the Enlarged Single European M arket 32: 215-240.

Turner L. (1991) The Politics of Work Reorganization: Pervasive Union Decline?. Democracy at work: Changing world markets and the future of labor unions. Ithaca, NY: ILR Press/Cornell University Press.

Van Drongelen H. and De Kort H. (2016) Betaling van het minimumloon en de bestuursrechtelijke ketenaanpak. Tijdschrift voor Arbeid \& Onderneming 1: 6-10.

Wagner I. (2015) Rule Enactment in a Pan European Labour M arket: Transnational Posted Work in the German Construction Sector. British Journal of Industrial Relations 53 (4): 692-710.

Wagner I. and Lillie N. (2014) European Integration and the Disembedding of Labour M arket Regulation: Transnational Labour Relations at the European Central Bank Construction Site. JCM S: Journal of Common Market Studies 52 (2): 403-419.

Zhang C. and Lillie N. (2015) Industrial citizenship, cosmopolitanism and European integration. European Journal of Social Theory 18 (1): 93-111. 


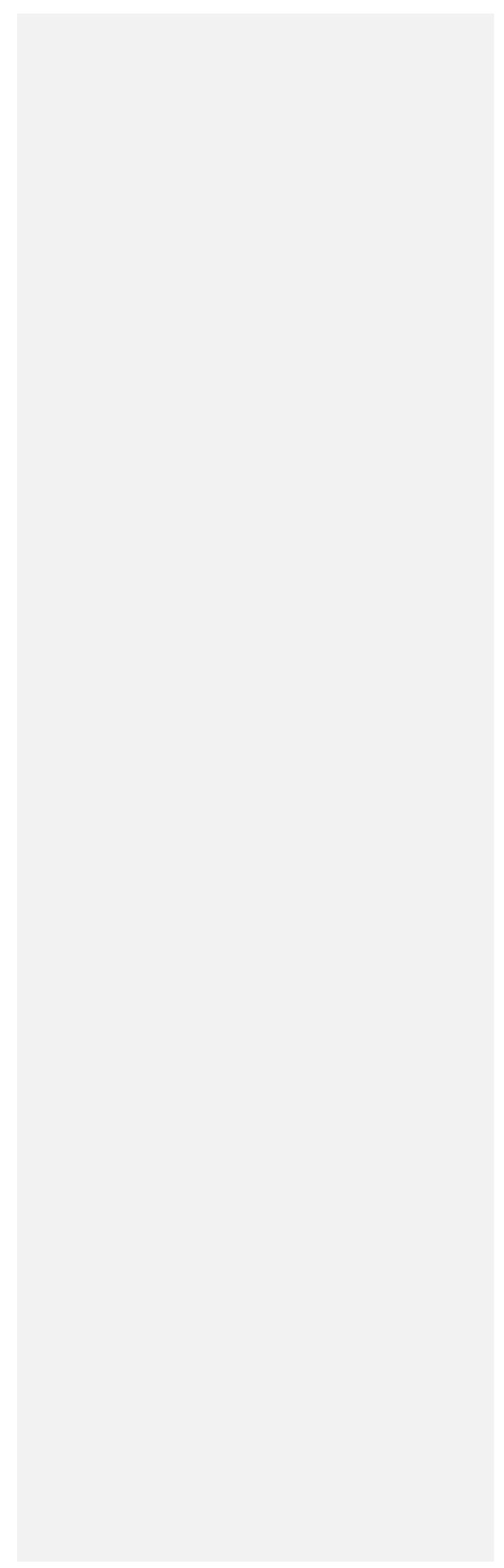

